\title{
Solvent Extraction of a South African Bituminous Coal using a Model Biomass-derived Phenolic Mixture
}

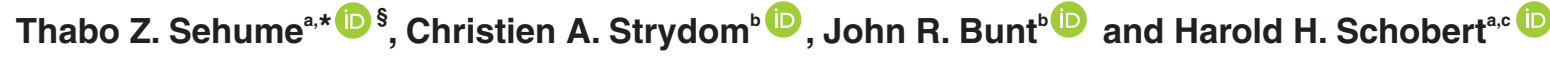 \\ ${ }^{a}$ Chemical Resource Beneficiation, North-West University, Potchefstroom Campus, Private Bag X6001, Potchefstroom, 2520, South Africa. \\ ${ }^{b}$ Centre of Excellence in Carbon-based fuels, Faculty of Engineering, North-West University, Potchefstroom Campus, \\ Private Bag X6001, Potchefstroom, 2520, South Africa. \\ ${ }^{c}$ Department of Energy and Mineral Engineering \& The EMS Energy Institute, The Pennsylvania State University, University Park, \\ Pennsylvania 16802 U.S.A.
}

Received 2 April 2019, revised 15 August 2019, accepted 28 August 2019.

\begin{abstract}
A model biomass-derived phenolic mixture was investigated for its solvent ability for extraction of a South African bituminous coal at temperatures of $300-360^{\circ} \mathrm{C}$. A previous study showed that phenol gave the highest extraction yield of $49.5 \mathrm{wt}$. $\%$ (daf) for bituminous coal at $360^{\circ} \mathrm{C}$, with an oil yield of $26.3 \mathrm{wt}$. \% (daf). The phenolic products produced from sweet sorghum bagasse via an alkaline liquefaction process were identified and reported earlier and a model biomass-derived phenolic mixture was formulated, evaluated and results used in this study. The model mixture gave an extraction yield of $37.1 \mathrm{wt}$ \% (daf) and oil yield of $16.9 \mathrm{wt} . \%$ (daf) at $360^{\circ} \mathrm{C}$. This solvent mixture was found to be less effective for high extraction yields when compared to phenol at mild temperatures. This could be due to phenol being a better hydrogen carrier than the solvent mixture during the internal redistribution of hydrogen in the coal. The infrared spectroscopy results of the coal and extraction products obtained using the model mixtures showed similar functional groups. These results demonstrate that the use of a model biomass-derived phenolic mixture has the potential to depolymerize coal and produce high-value chemicals from coal.
\end{abstract}

KEYWORDS

Coal extraction, bituminous coal, depolymerization, biomass-derived solvent.

\section{Introduction}

South Africa relies on its abundant coal reserves to meet much of its energy demand. Coal provides $79 \%$ of the country's total energy needs. ${ }^{1,2}$ The country's synthetic liquid fuel production contributes $40 \%$ to the total liquid fuel demand. The remaining $60 \%$ is sourced from the refining of imported crude oil. ${ }^{1,3}$ The production of liquid transportation fuels synthesized from coal provides an important alternative solution to augment the petroleum supply, thus reducing the dependency on imported petroleum and helping to relieve strained refinery capacity. ${ }^{4-6}$ Sasol runs an indirect liquefaction process for the production of liquid fuels and chemicals from coal. The indirect coal liquefaction facility in South Africa produces approximately 160000 barrels of crude oil equivalent a day. ${ }^{1,7}$ However, the currently favoured approach to producing synthetic liquid fuels, coal gasification followed by the Fischer-Tropsch process, poses challenges. ${ }^{8}$ For example, this includes the by-product of this process, namely carbon dioxide $\left(\mathrm{CO}_{2}\right)$, a greenhouse gas associated with global warming. ${ }^{9}$ Furthermore, a large amount of hydrogen is used for coal processing through coal liquefaction, which raises cost and energy consumption. ${ }^{10}$ In this study, we examine the potential of solvent extraction for coal conversion. This process is an alternative coal conversion process that can produce coal-derived liquids without hydrogen and also at lower temperatures.

Coal extraction with an appropriate solvent can be used to study the composition, structure of coal and also as a conversion process to produce value-added products from coal. The solvent extraction process and explanation of the terms used to describe the process (i.e. decomposition and depolymerization) was summarized by Sehume et al. ${ }^{11}$ In general, solvent extraction represents the treatment of coal with a solvent(s) to dissolve some components of the coal, at temperatures between 200 and $400{ }^{\circ} \mathrm{C} .11,12$ The extensive experiments, using phenol as a solvent, for solvent extraction of coal date back to the 1920s. ${ }^{13,14,15}$ This approach was found to be ideal as it is performed at temperatures close to the boiling point of the solvent for higher extraction yields. ${ }^{12}$ It was reported that repeated extraction at increasingly higher temperatures leads to a continuous increase in extract yield. ${ }^{16}$ The change in the extract yield has been related to the chemical nature of the solvent at higher temperatures. ${ }^{17,18}$ According to Berkowitz, ${ }^{19}$ at temperatures below $\approx 350{ }^{\circ} \mathrm{C}$, the solvent potency may depend on the ability of the solvent to swell, peptize, and promote coal depolymerization; and the most effective solvents are aromatics and hydroxylated aromatics (i.e. phenol, naphthalene, $\alpha$ - and $\beta$-naphthols, phenyl phenols, anthraces, or phenanthrene). Orchin and Starch ${ }^{20}$ evaluated a variety of solvents for their ability to extract coals and showed that hydroaromatic solvents containing a phenolic group were superior to those without one. In addition, the presence of a phenolic $\mathrm{OH}$ usually leads to high extraction, but not always. However, these authors did not state at which conditions phenolic $\mathrm{OH}$ will not lead to high extraction yields. Aromatic compounds, such as naphthalene, cresol, diphenyl, or o-phenylphenol, have been reported in the literature of being able to dissolve $20-30 \%$ of the coal at $400{ }^{\circ} \mathrm{C} .{ }^{21}$ Other studies have shown that coal extraction with a single solvent in the system can be limited depending on factors, such as extraction yield and

* To whom correspondence should be addressed. E-mail: zsehume@ gmail.com 
solvent swelling. ${ }^{18,21-23}$ Coal extraction with some of the solvent mixtures can lead to high yields of extract. ${ }^{16,18,22-24}$ The influence of the mixed solvents was explained by the increase in the penetration of solvents into coals by coal swelling. ${ }^{25} \mathrm{Kuznetnov}^{18}$ have reported a coal extraction yield of 30-40\% using a solvent mixture (1:1) of tetralin-phenol, and naphthalene-phenol, quinoline-phenol. Miura and $\mathrm{Mae}^{24}$ reported a high coal extraction yield with carbolic oil (composed of phenolic compounds), as an extraction solvent. They reported that the role of this solvent is to dissociate hydrogen bonds between coal structures, namely, the physical effect rather than the chemical effect. ${ }^{26}$ Aida et al..$^{23}$ extracted coal with supercritical water-phenol mixtures near $400^{\circ} \mathrm{C}$. They observed that the extraction yield increased as the ratio of phenol-water was increased, showing a maximum of $70 \%$ at a water-phenol ratio of 4.5:0.5 and then reduced to $50-55 \%$ for phenol. Recently, Sehume et al. ${ }^{11}$ showed that phenol has the potential to extract up to $50 \mathrm{wt}$. \% (daf) of a South African bituminous coal at a temperature of $360{ }^{\circ} \mathrm{C}$. It was of interest to investigate a renewable energy source material (i.e. derived from biomass) that can produce phenolic-rich compounds that could subsequently be used to facilitate the production of useful liquids from South African coals.

Sehume et al. ${ }^{27}$ identified the phenolic compounds obtained from a sweet sorghum bagasse biomass sample, which was subjected to liquefaction using an alkaline treatment method at low reaction temperatures. The main phenolic compounds produced at a temperature of $280^{\circ} \mathrm{C}$ and a $\mathrm{NaOH}$ concentration of $3.0 \mathrm{M}$ were phenol (13.8 wt. \% of total liquid products), p-cresol (6.8 wt. \%), 4-ethylphenol (10.0 wt. \%), 4-isopropylphenol (0.9 wt. \%), 2-propylphenol (0.7 wt. \%), and 4-ethylguaicol $(1.5 \mathrm{wt}$. \%). The model biomass-derived phenolic mixture was formulated based on the constituents as in the above-mentioned phenolic extraction results. We report in this paper on the utilization of a model biomass-derived phenolic mixture as a solvent for the bituminous coal in comparison to the use of phenol.

\section{Experimental Section}

\subsection{Materials}

South African bituminous coal (Waterberg) was supplied by Exxaro Resources Limited (South Africa). ${ }^{11}$ Sample sizes of less than $150 \mu \mathrm{m}$ were used in this investigation. A model biomass derived-phenolic mixture was based on the prominence of phenolic species identified in a previous study. ${ }^{27}$ Liquified phenol (purity $\geq 89.0 \%$ and impurities $\approx 10 \%$, water) was supplied by Sigma-Aldrich (South Africa). The following phenol derivatives' were purchased from Minema Chemicals (South Africa); p-cresol (99\%), 4-ethylphenol (99\%), 4-isopropylphenol (98\%), 2-propylphenol (97\%), and 4-ethylguaicol (98\%). The phenols were mixed prior to the solvent extraction and used without further purification. The weight ratio of the phenol: p-cresol: 4-ethylphenol: 2-propylphenol: 4-isopropylphenol: 4-ethylguaicol was 4:2:3:0.3:0.2:0.5. $\mathrm{N}_{2}$ (high purity, $99.999 \%$ ) was supplied by Africa Oxygen Limited (AFROX, South Africa). Tetrahydrofuran (THF) and n-hexane were purchased from Merck Chemicals (Pty) Ltd, South Africa.

\subsection{Solvent Extraction Process and Characterization of Products}

All experiments were conducted in a stainless-steel highpressure autoclave as described by Sehume et al. ${ }^{11}$ The autoclave was charged with a weight ratio of 1:10 coal to solvent (model biomass-derived phenolic mixture). Darlage and Bailey ${ }^{28}$ also investigated solvent effects in depolymerization of coal using coal: phenol ratio of 1:10. The reactor was sealed and flushed with $\mathrm{N}_{2}$. The autoclave was pressurized and heated to the reaction temperature in an $\mathrm{N}_{2}$ atmosphere (initial cold pressure of $0.5 \mathrm{MPa}$ ) at a heating rate of $4{ }^{\circ} \mathrm{C} \mathrm{min}^{-1}$. The coal solvent extraction process was performed at reaction temperatures of 300, 320, 340 and $360{ }^{\circ} \mathrm{C}$, whilst magnetically stirring the mixture at $300 \mathrm{rpm}$. The autoclave was held for $20 \mathrm{~min}$ at each specified maximum temperature $\left( \pm 4^{\circ} \mathrm{C}\right)$, and then cooled down to room temperature using an electric fan. The product mixtures (solid and liquid) were vacuum filtered and the gases produced were calculated according to mass balance. A series of extractions were carried out on the filtered liquid (after solvent extraction) using a reflux system with two solvents at $85{ }^{\circ} \mathrm{C}$ for $1 \mathrm{~h}$, as described in a previous study. ${ }^{11}$ The THF-insoluble part of the liquid residue was labelled THFI and represents the unreacted portion of the coal. The THF-soluble part of the liquid residue (THFS) was further extracted with hexane, and the hexaneinsoluble part of this extraction step (HI) was labelled PAAs, as it contains a combination of preasphaltenes and asphaltenes. The hexane-soluble(HS) product contains the oil part of the product.

\subsection{Characterization of Coal and Extraction Products}

Proximate analyses were performed using a U-Therm TGA thermogravimetric analyzer, and ultimate analyses of the coal and solvent extraction products were carried out using an Elemental Vario El cube elemental analyzer, according to the ASTM 29541 method. ${ }^{11}$ The oxygen content was calculated by difference. Each sample was characterized three times and the averages were used. The petrographic analysis was conducted by the Council for Geoscience (South Africa) using a Leica DM600 microscope with a Carl Hilgers motorized system, according to the ISO 7404-2 method.

The model biomass-derived phenolic mixture was characterized by GC/MS using an Agilent gas chromatograph (GC), model $6890 \mathrm{~N}$ coupled with an Agilent mass spectrometer detector (MS), model 5975B Inert XL EI/CI equipped with a CTC Analytics PAL autosampler. The GC was equipped with a capillary column (Agilent 19091S; $30 \mathrm{~m}$ length, $0.25 \mathrm{~mm}$ inner diameter, $0.25 \mu \mathrm{m}$ film thickness). The oven temperature program was as follows: $30^{\circ} \mathrm{C}$ held for $2 \mathrm{~min}$, then ramped up to $320^{\circ} \mathrm{C}$ at $5{ }^{\circ} \mathrm{C} \mathrm{min}^{-1}$ and held for $10 \mathrm{~min}$. The total run time for the method was $50 \mathrm{~min}$. Helium at a constant flow rate of $1.0 \mathrm{~mL} \mathrm{~min}^{-1}$ was used as a carrier gas. The injector was operated with a split ratio of $1 / 15$ that was maintained at $250{ }^{\circ} \mathrm{C}$ throughout the analysis. The National Institute of Standards and Technology (NIST) spectral library was used for peak identification.

Samples were analyzed using an attenuated total reflection Bruker Fourier Transform Infra-Red spectrometer (ATR-FTIR) with an ALPHA's Platinum ATR single reflection diamond ATR module, at ambient temperature in the region of 400 to $4000 \mathrm{~cm}^{-1}$. Infrared spectroscopy was used to elucidate the effect of the solvent extraction process on the functional groups of the products that were obtained at different temperatures.

The pyrolysis behaviour of the coal and PAAs was studied by thermogravimetric analysis (TGA, SDTQ600). Samples of approximately $12 \mathrm{mg}$ were analyzed. Thermogravimetric (TG) and derivative thermogravimetric (DTG) profiles of both the coal and the solid residues were obtained using a heating rate of

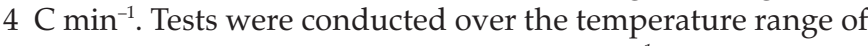
60-900 ${ }^{\circ} \mathrm{C}$ under a nitrogen flow of $75 \mathrm{~mL} \mathrm{~min}^{-1}$.

Simulated distillation (SimDis) analyses were carried out using an HP Model 5890 GC system, in accordance with the ASTM D2887 method. The analysis was carried out on a high-tempera- 
ture GC-FID system that has been fitted with an ARX 2887 Restek column $(10 \mathrm{~m} \times 0.53 \mathrm{~mm} \times 0.53 \mu \mathrm{m})$. This process was followed by the injection of $\sim 0.2 \mu \mathrm{L}$ of the fractions into the GC column. The distillation curves were determined on a solventfree basis.

The overall percentage conversion or extraction yield of coal during the solvent extraction, using a model biomass-derived phenolic mixture as the solvent, was calculated according to the equation (all values indicated are weight percentages): ${ }^{11}$

Conversion or extraction yield (wt. \%) $=$ [coal charged unreacted coal residue $(\mathrm{THFI}) /$ daf coal $] \times 100 \%$.

The yield of pre-asphaltenes and asphaltenes (PAAs, HI) is defined by:

PAAs (wt. \%) $=[($ Hexane insoluble material, THF soluble $) /$

daf coal $] \times 100 \%$

where daf coal is the weight of the dry, ash-free coal.

The oil part of the extracted products (HS) is obtained by difference:

oil $($ wt. $\%)=[$ Conversion $-($ PAAs $)-G] \times 100 \%$

where $\mathrm{G}$ is the yield of the gaseous products obtained after the coal solvent extraction (obtained by mass balance). The conversion or extraction yield and intermediate products yields (PAAs) were determined gravimetrically, based on the solvent-free dried residues.

\section{Results and Discussion}

\subsection{GC-MS (Semi-quantitative) Analysis of the}

Model Biomass-derived Phenolic Mixture

The GC-MS analysis was performed on the model biomassderived phenolic mixture prior to solvent extraction and the results are shown in Fig. 1. The area percentages of the phenolic compounds were 39.91, 17.42, 32.78, 2.05, 1.86 and $5.98 \%$ for phenol, p-cresol, 4-ethylphenol, 2-propylphenol, 4-isopropylphenol, and 4-ethylguaicol, respectively (Fig. 1).

\subsection{Characterization of Samples}

The elemental analysis, X-ray fluorescence (XRF) and maceral composition results as reported earlier for the coal are summarized in Table $1 .{ }^{11}$ The proximate and ultimate analyses shows that the coal compromises of $34 \mathrm{wt}$ \% (ad) volatile matter, 50 wt. \% (ad) fixed carbon and 81 wt. \% (daf) carbon content. The most abundant oxides in the ash were $\mathrm{SiO}_{2}(62.3 \%), \mathrm{Al}_{2} \mathrm{O}_{3}$ $(20.4 \%)$ and $\mathrm{Fe}_{2} \mathrm{O}_{3}(8.7 \%)$ contributing up to $91.4 \%$ of the total ash composition (Table 1). In most bituminous coals a portion of the $\mathrm{SiO}_{2}$ may be present as free quartz; however, much or all of the $\mathrm{SiO}_{2}$ is likely present in clays. All of the $\mathrm{Al}_{2} \mathrm{O}_{3}$ will be in clays or similar minerals. Probably most or all of any $\mathrm{Fe}_{2} \mathrm{O}_{3}$ are due to the oxidation of pyrite, $\mathrm{FeS}_{2}$, during the ashing process. The petrographic constituents of this coal decreased in the order vitrinite $(52.8 \%)$, inertinite $(29.4 \%)$, reactive semifusinite $(6.7 \%)$, and liptinite $(3.5 \%)$.

In Table 2, the results from the proximate analysis of the unreacted coal residues (THFIs) and the extraction products (PAAs) after the solvent extraction treatment are summarized. The results show that the ash percentages of THFIs increased from 10.4 and $14.2 \mathrm{wt}$. \% with increasing extraction temperatures between $300{ }^{\circ} \mathrm{C}$ and $360{ }^{\circ} \mathrm{C}$. The inorganic materials in the coal are largely or completely un-extracted, while the amount of organic substance extracted increases with temperature. Therefore, inevitably the ash yield will increase as observed in this study. The ash percentage trend is also similar to the results obtained through the use of pure phenol (10.4 wt. \% up to 20.6 wt. \%). ${ }^{11}$ The volatile matter contents of approximately $45 \mathrm{wt}$. \% and ash percentages of approximately $0.3 \mathrm{wt}$. \% of the PAAs remain constant at the various experimental temperatures for the solvent extraction process reported in this study. The nitrogen and sulphur contents of THFIs $\left(300-360^{\circ} \mathrm{C}\right)$ were somewhat lower than that observed for the coal. In general, the ultimate

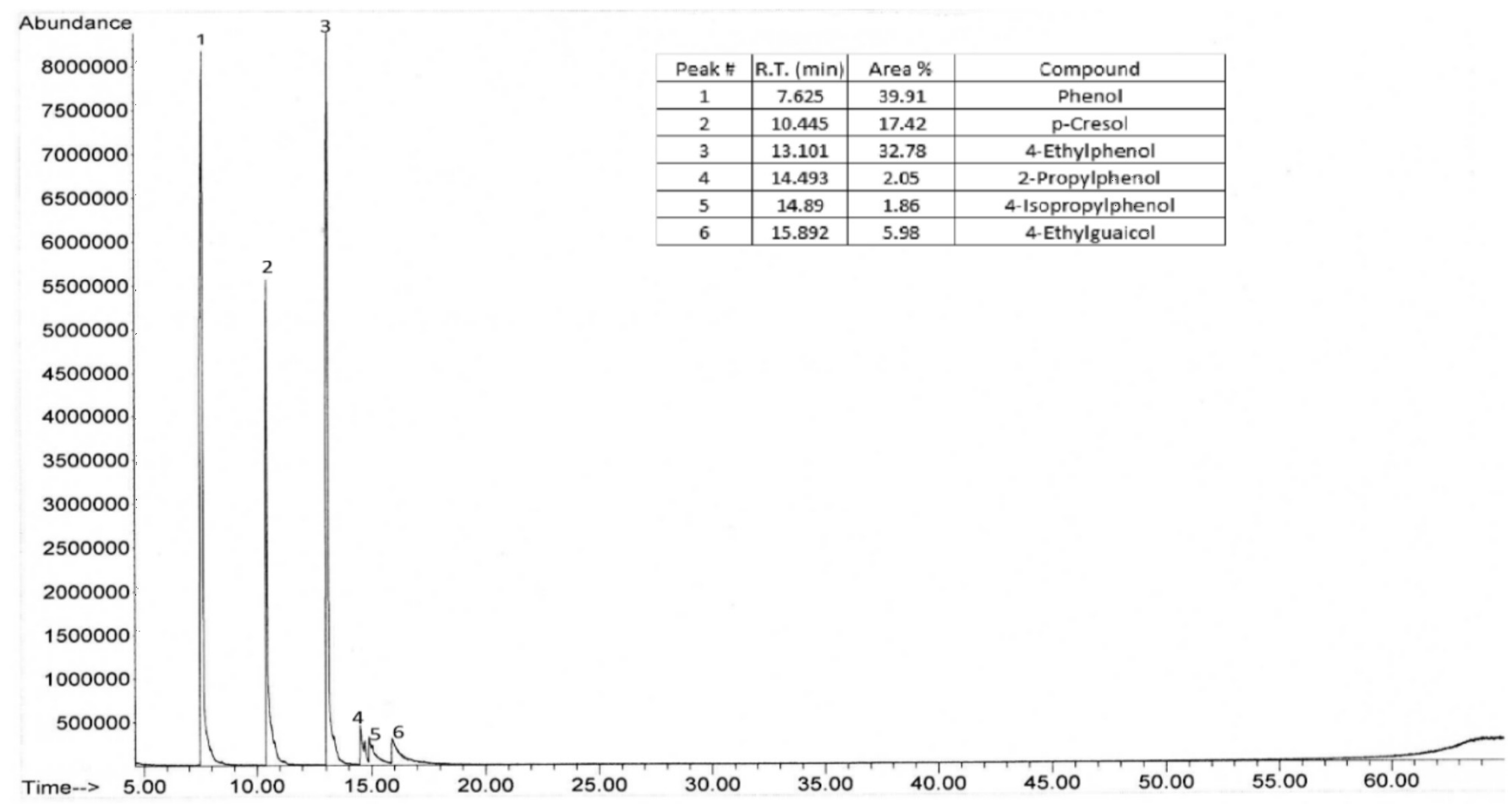

Figure 1 GC-MS spectrum of the model biomass-derived phenolic mixture 
Table 1 Proximate ultimate, XRF and petrographic results for the coal. ${ }^{11}$

\begin{tabular}{|c|c|c|}
\hline Chemical properties & $\begin{array}{l}\text { Standard methods } \\
\text { used }\end{array}$ & Coal \\
\hline \multicolumn{3}{|l|}{ Proximate analysis (wt. $\%$, ad) ${ }^{a}$} \\
\hline Inherent Moisture & ISO11722 & 3.1 \\
\hline Volatile matter & ISO 562 & 34.2 \\
\hline Ash & ISO 1171 & 10.9 \\
\hline Fixed carbon & By difference & 51.8 \\
\hline Ultimate analysis (wt. $\%$, daf) ${ }^{\mathrm{b}}$ & \multicolumn{2}{|l|}{ ISO 29541} \\
\hline Carbon & & 80.9 \\
\hline Hydrogen & & 5.5 \\
\hline Nitrogen & & 1.9 \\
\hline Sulphur & ISO 19579 & 1.3 \\
\hline Oxygen & By difference & 10.4 \\
\hline $\mathrm{H} / \mathrm{C}$ (Atomic ratio) & & 0.82 \\
\hline
\end{tabular}

Dilatation SANS 6072

\begin{tabular}{lc}
\hline Softening temperature $\left({ }^{\circ} \mathrm{C}\right)$ & 397 \\
Temperature of maximum contraction $\left({ }^{\circ} \mathrm{C}\right)$ & 501 \\
Maximum contraction $(\%)$ & 27 \\
\hline
\end{tabular}

\begin{tabular}{lc}
\hline XRF $($ wt. \%) & ASTM D4326 \\
\hline $\mathrm{Fe}_{2} \mathrm{O}_{3}$ & 8.7 \\
$\mathrm{MnO}$ & 0.1 \\
$\mathrm{Cr}_{2} \mathrm{O}_{3}$ & 0.1 \\
$\mathrm{~V}_{2} \mathrm{O}_{5}$ & 0.2 \\
$\mathrm{TiO}_{2}$ & 2.6 \\
$\mathrm{CaO}$ & 1.4 \\
$\mathrm{~K}_{2} \mathrm{O}$ & 1.0 \\
$\mathrm{P}_{2} \mathrm{O}_{5}$ & 0.1 \\
$\mathrm{SiO}_{2}$ & 62.3 \\
$\mathrm{Al}_{2} \mathrm{O}_{3}$ & 20.4 \\
$\mathrm{MgO}^{\mathrm{ZnO}}$ & 0.8 \\
$\mathrm{SO}_{3}$ & 1.1 \\
\hline
\end{tabular}

\begin{tabular}{lc}
\hline Petrographic analysis (vol. \%, m.m.f.b.) & ISO 7404-2 \\
\hline Vitrinite & 52.8 \\
Liptinite & 3.5 \\
Reactive semifusinite & 6.7 \\
Total inertinite & 29.4 \\
Visible mineral matter & 7.5 \\
Vitrinite reflectance & 0.6 \\
\hline
\end{tabular}

* aad: air-dried basis

* bdaf: dry-ash-free basis.

* Note - Gieseler fluidity and some values from dilatation were not determined due to sample size.

analysis characterization results of THFIs and PAAs using a model biomass-derived phenolic mixture are similar to results obtained in a previous study using phenol. ${ }^{11}$

\subsection{Coal Conversion as a Function of Temperature and Product Distribution}

Figure 2 shows the coal conversion and overall product distribution after solvent extraction at $300-360^{\circ} \mathrm{C}$ using a model biomass-derived phenolic mixture. As the temperature increases, the yield of the residue (THFIs) decreases, while the conversion increases. Using pure phenol as a solvent the same trend was observed. ${ }^{11}$ Figure 2 shows the coal conversions of 14 wt. $\%$, 20 wt. $\%, 32$ wt. $\%$ and $37 \mathrm{wt}$. $\%$ using a model biomass-derived phenolic mixture at $300{ }^{\circ} \mathrm{C}, 320{ }^{\circ} \mathrm{C}, 340{ }^{\circ} \mathrm{C}$ and $360{ }^{\circ} \mathrm{C}$. The yield of the solid residues (THFIs) during the solvent extraction decreased from 86 to 63 wt. \% (daf) when treated between $300{ }^{\circ} \mathrm{C}$ and $360{ }^{\circ} \mathrm{C}$. Pew and Withrow ${ }^{29}$ reported approximately 43.6 wt. \% extract and 63.8 wt. \% residue after solvent extraction of a Pittsburgh No. 8 seam coal using phenol in an atmosphere of carbon dioxide. Kiebler ${ }^{30}$ observed extracts of 39.7, 40.4 and 49.1 wt. \% for Pittsburgh seam coal with phenol, m-cresol and o-phenyl phenol, respectively. However, their results showed that the solvents which gave the greatest yield of extract appeared to be most affected by oxidation, based on a high material balance $(>100 \%)$. Fieldner and Ambrose ${ }^{21}$ reported that compounds, such as cresol, diphenyl, or o-phenylphenol, could only dissolve $20-30 \%$ of the coal. Larry and Bailey ${ }^{28}$ observed extraction yields of $32 \mathrm{wt}$. \% and $36 \mathrm{wt}$. \% daf for phenol/o-cresol and phenol/catechol solvent mixtures in the presence of a catalyst (sulphuric acid), respectively, using high-volatile bituminous coal from the Pond Creek seam. Some of these results corresponded with the conversion yield of nearly $37 \mathrm{wt}$. \% obtained at $360{ }^{\circ} \mathrm{C}$. However, this value was lower than that obtained in the experiments where pure phenol was used as a solvent, where conversion of nearly $50 \mathrm{wt}$. \% was observed. ${ }^{11}$ The effectivity of phenol-based solvents is characterized significantly by their ability to dissolve or penetrate coal structure. ${ }^{25}$ Larsen et al. ${ }^{31}$ reported that phenol can readily give up a hydrogen atom to form a phenoxy radical. The phenoxy radicals are capable of abstracting a hydrogen atom from a good donor site in the coal, regenerating phenol. Therefore, phenol may serve as a good hydrogen carrier. Alkyl-substituted phenols were reported to be undesirable due to the formation of benzylic radicals resulting in the incorporation of the alkyl phenol into the coal structure. ${ }^{32}$

\subsection{The Effect of Temperature on Gas Yields during Solvent Extraction}

The gaseous product yields obtained after coal solvent extraction at temperatures of $300-360{ }^{\circ} \mathrm{C}$ through mass balance are shown in Fig. 3. The temperature range above $250{ }^{\circ} \mathrm{C}$ has been reported to mark the onset of the active thermal decomposition of bituminous coal. ${ }^{19,33}$ As it can be seen from Table 1 (dilatation results) that the coal used in this study begins to soften at about $397^{\circ} \mathrm{C}$. The results show that gaseous products progressively increased with increasing temperature (7-9.6 wt. \%). Similar trends were also reported for coal extraction using phenol as a solvent $\left(300-360{ }^{\circ} \mathrm{C}\right) .{ }^{11}$ However, the gaseous yields of the present study, using a model biomass-derived phenolic mixture, were slightly more than that obtained in a previous study using phenol, where the yields were $4.9,6.2,6.3$ and 6.4 wt. $\%$ at 300 , 320,340 and $360{ }^{\circ} \mathrm{C} .{ }^{11}$ It is more likely that the gaseous products can be due to gases that could have been chemisorbed onto the coal surface, apart from the gases resulted from the thermal rupture of the labile bonds in the coal structure.

\subsection{The Effect of Temperature on PAAs during Solvent Extraction}

Figure 4 shows the effect of temperature on the conversion of coal and PAAs during the coal extraction process using a model biomass-derived phenolic mixture. It can be seen from Fig. 4 that the conversion increased from 14 to $37 \mathrm{wt}$. \% with increasing reaction temperatures $\left(300-360^{\circ} \mathrm{C}\right)$. The PAAs are an intermediate product in coal extraction or liquefaction which can be further converted to oil and/or gases. ${ }^{34,35}$ PAAs were grouped together as one fraction due to the similarity in their dissolving ability in THF and n-hexane. ${ }^{35}$ The yield of PAAs slowly (4-7 wt. \%) increased as the temperature increased between $300{ }^{\circ} \mathrm{C}$ and $320^{\circ} \mathrm{C}$ which is in the range of the thermal decompo- 
Table 2 Proximate and ultimate analyses of coal solvent extraction products using a model biomass-derived phenolic mixture and phenol ${ }^{11}$ (unreacted coal residues (THFIs) and PAAs).

\begin{tabular}{|c|c|c|c|c|c|c|c|c|c|c|}
\hline Product & $\begin{array}{l}\text { Chemical } \\
\text { properties }\end{array}$ & $\begin{array}{l}\text { Standard } \\
\text { methods }\end{array}$ & $300{ }^{\circ} \mathrm{C}$ & $300{ }^{\circ} \mathrm{C}^{11}$ & $320^{\circ} \mathrm{C}$ & $320^{\circ} \mathrm{C}^{11}$ & $340^{\circ} \mathrm{C}$ & $340{ }^{\circ} \mathrm{C}^{11}$ & $360^{\circ} \mathrm{C}$ & $360^{\circ} \mathrm{C}^{11}$ \\
\hline & \multicolumn{10}{|c|}{ Proximate analysis (wt.\%, air-dry basis) } \\
\hline & Moisture & ISO11722 & 1.8 & 2.0 & 2.2 & 2.1 & 2.6 & 2.8 & 2.6 & 2.6 \\
\hline & Volatile Matter & ISO 5621 & 39.9 & 44.7 & 38.3 & 43.0 & 35.9 & 31.7 & 32.3 & 28.5 \\
\hline & Ash & ISO 1171 & 10.4 & 10.2 & 11.3 & 10.5 & 12.3 & 18.5 & 14.4 & 20.6 \\
\hline & Fixed Carbon & By difference & 47.9 & 43.1 & 48.2 & 44.4 & 49.2 & 47.0 & 50.7 & 48.3 \\
\hline \multirow[t]{12}{*}{ THFIs } & \multicolumn{10}{|c|}{ Ultimate analysis (wt.\%, dry-ash-free basis) ISO 29541} \\
\hline & Carbon & & 77.9 & 79.1 & 81.3 & 79 & 81.9 & 82.9 & 82.2 & 82.2 \\
\hline & Hydrogen & & 5.1 & 5.1 & 5.3 & 4.8 & 5.3 & 5.1 & 5.1 & 4.8 \\
\hline & Nitrogen & & 1.6 & 1.6 & 1.5 & 1.6 & 1.4 & 1.9 & 1.6 & 2.0 \\
\hline & Sulphur & D4239-14 & 1.2 & 0.9 & 1.1 & 0.9 & 1.1 & 1.0 & 1.2 & 1.1 \\
\hline & Oxygen & By difference & 14.2 & 13.3 & 10.8 & 13.7 & 10.3 & 9.1 & 9.9 & 9.9 \\
\hline & $\mathrm{H} / \mathrm{C}$ (Atomic ratio) & & 0.79 & 0.77 & 0.78 & 0.73 & 0.78 & 0.74 & 0.74 & 0.70 \\
\hline & \multicolumn{10}{|c|}{ Proximate analysis (wt. \%, air-dried basis) } \\
\hline & Moisture & ISO11722 & 2.6 & 1.7 & 3.2 & 2.2 & 3.4 & 2.1 & 2.4 & 2.2 \\
\hline & Volatile Matter & ISO 5621 & 45.5 & 56.2 & 46.5 & 57.1 & 45.9 & 54.0 & 46.9 & 55.5 \\
\hline & Ash & ISO 1171 & 0.3 & 0.9 & 0.2 & 0.8 & 0.3 & 0.9 & 0.3 & 0.9 \\
\hline & Fixed Carbon & By difference & 51.6 & 41.2 & 50.1 & 39.9 & 50.4 & 43.0 & 50.4 & 41.4 \\
\hline \multirow[t]{7}{*}{ PAAs } & \multicolumn{10}{|c|}{ Ultimate analysis (wt.\%, dry-ash-free basis) ISO 29541} \\
\hline & Carbon & & & & & & & & & \\
\hline & Hydrogen & & 80.7 & 80.1 & 81.8 & 80.8 & 81.1 & 81.3 & 80.9 & 81.8 \\
\hline & Nitrogen & & 5.4 & 5.1 & 5.5 & 5.2 & 5.3 & 5.1 & 5.3 & 5.1 \\
\hline & Sulphur & & 1.5 & 2.0 & 1.3 & 1.9 & 1.3 & 2.0 & 1.4 & 1.8 \\
\hline & Oxygen & D4239-14 & 0.7 & 0.7 & 0.7 & 0.7 & 0.7 & 0.8 & 0.6 & 0.7 \\
\hline & $\mathrm{H} / \mathrm{C}$ (atomic ratio) & By difference & 11.7 & 12.1 & 10.7 & 11.4 & 11.6 & 10.8 & 11.8 & 10.6 \\
\hline
\end{tabular}

sition of the coal..$^{11}$ Between $320{ }^{\circ} \mathrm{C}$ and $340{ }^{\circ} \mathrm{C}$, the PAAs yields increased, which also parallels the increasing conversion as a function of temperature in this temperature range. In the present study, the yield of PAAs (15-10 wt. \%) slowly decreased with increasing temperature between $340{ }^{\circ} \mathrm{C}$ and $360{ }^{\circ} \mathrm{C}$. This drop in the PAAs yield in this temperature range corresponds with an increase in the oil yield as a function of temperature (see below, Section 3.6). Similar trends were also reported for coal extraction using phenol at this temperature range. ${ }^{11}$

\subsection{The Effect of the Temperature on Oil Yield during Solvent Extraction}

The effect of temperature on the yield of oil after solvent extraction using a model biomass-derived phenolic mixture is

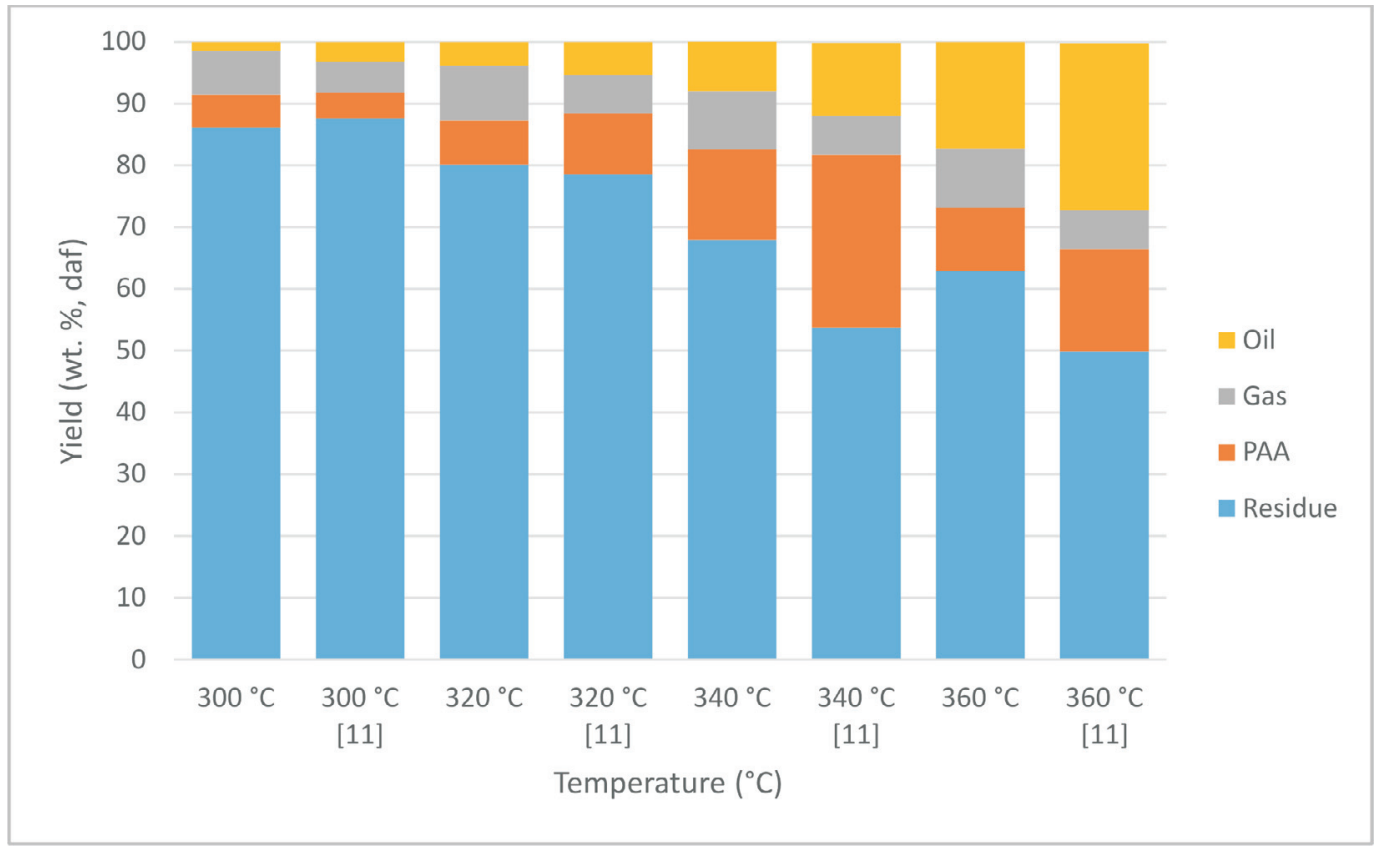

Figure 2 Coal conversion and extraction product distribution using a biomass-derived phenolic mixture and phenol. ${ }^{11}$ 


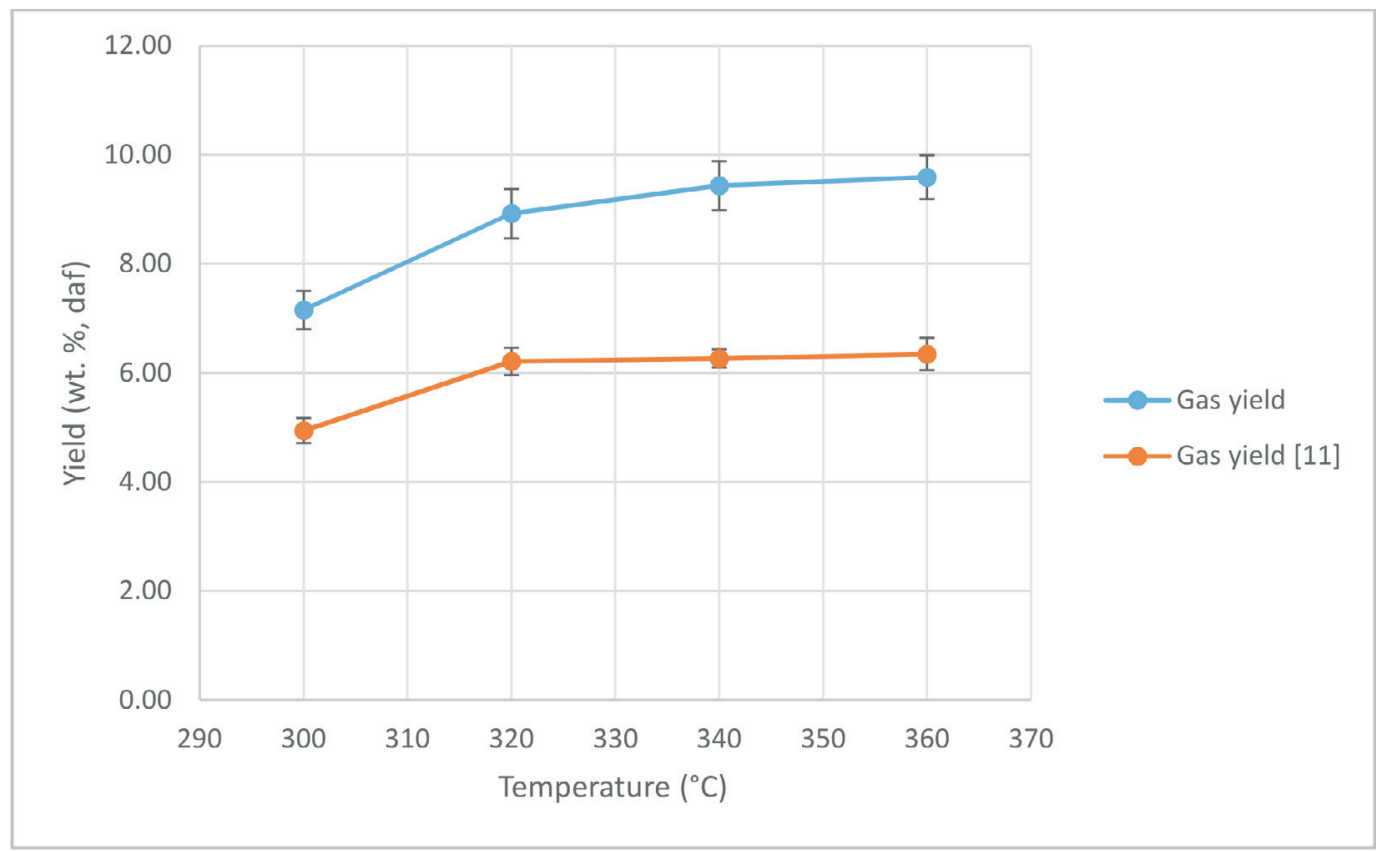

Figure 3 Gaseous products after solvent extraction using a model biomass-derived phenolic mixture and phenol. ${ }^{11}$

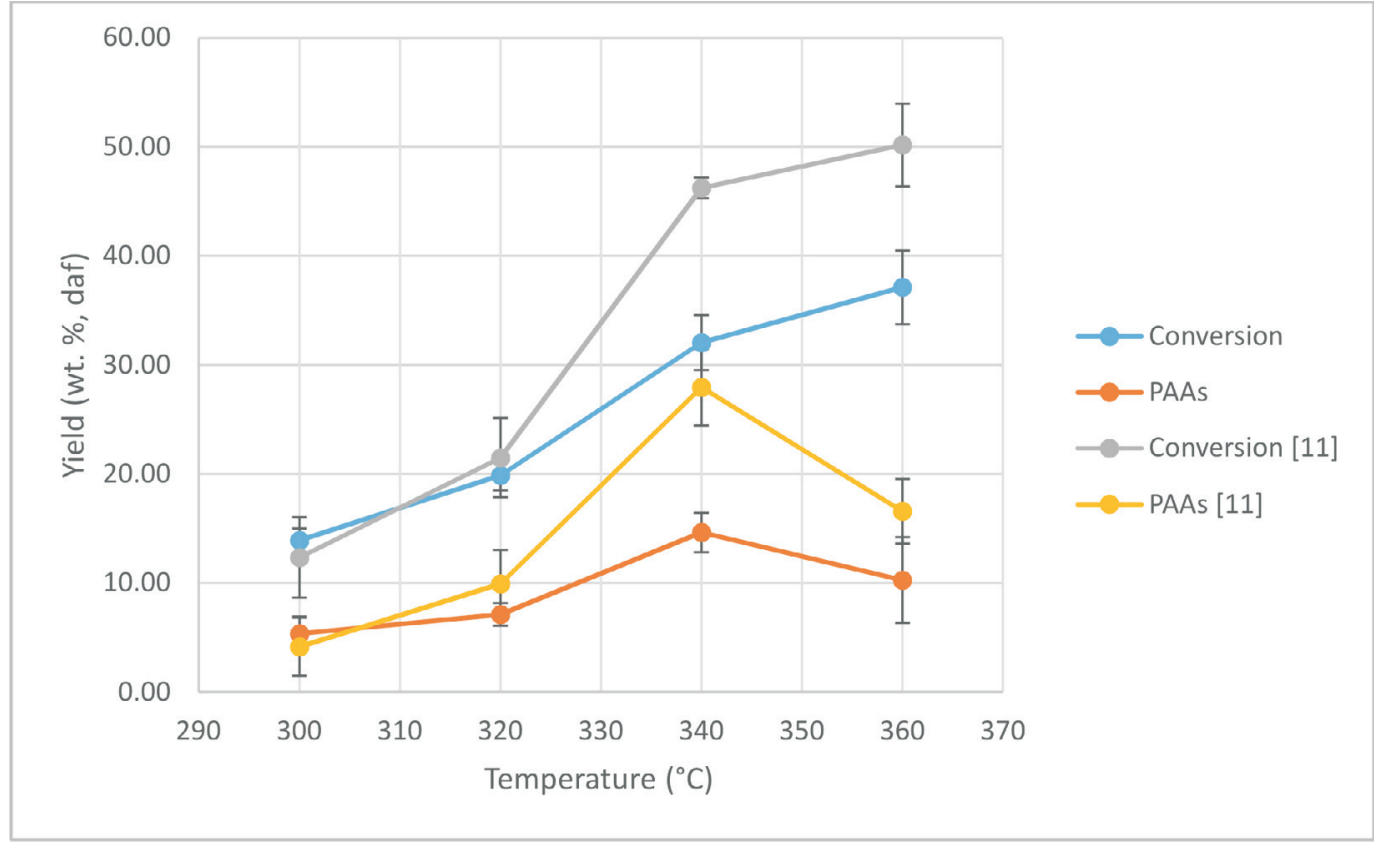

Figure 4 Coal conversion and PAAs yields using a model biomass-derived phenolic mixture and phenol. ${ }^{11}$

shown in Fig. 5. As shown earlier, an increase in the PAAs yield is coupled with higher coal conversions. The same trend is also observed with oil yields as coal is converted into solvent extraction products. From these results (Fig. 5), it can be seen that an increase in temperature also increased oil yields $\left(300-360{ }^{\circ} \mathrm{C}\right)$. The oil yield in this temperature range increased from $1 \mathrm{wt}$. \% to 17 wt. $\%$ and with the most significant change observed above $320^{\circ} \mathrm{C}$. The oil yield increased by nearly $5 \mathrm{wt}$. \% between extraction temperatures of $340{ }^{\circ} \mathrm{C}$ to $360{ }^{\circ} \mathrm{C}$, whilst the conversion increased by nearly $5 \mathrm{wt}$. \% . The oil yield observed at $360{ }^{\circ} \mathrm{C}$ using phenol as a solvent was higher, at 27 wt. \%, than the 17 wt. \% observed in this study using the biomass-derived phenolic mixture. ${ }^{11}$ The higher oil yields observed for phenol as a solvent are a result of phenol being a better hydrogen carrier during depolymerization of coal as compared to alkyl-substituted phenols, thus leading to higher coal extractions.

\subsection{ATR-FTIR Spectroscopy}

Figures 6-8 show the ATR-FTIR spectra of the coal, PAAs, and hexane soluble products (oil). ATR-FTIR spectrometry represents a relatively useful means of characterization of coal and coalderived products in terms of functional groups. Table 3 shows a summary of bands of the functional groups observed in Figs. 6-8.

These results show that the coal and the coal-derived products spectra were nearly similar in functional groups and with minimal apparent structural changes observed after extraction temperatures. ${ }^{42}$ The peaks within $700-800 \mathrm{~cm}-{ }^{1}$ can also be attributed to mineral matter especially in the case of the coal and THFI residues. However, the peaks around this region were observed to be weak for extraction products (HI and HS fractions) due to the absence of mineral matter. ${ }^{43}$ Similar results were observed for bituminous coal and extraction products using phenol as a single solvent system in a previous study. ${ }^{11}$ The FTIR results, 


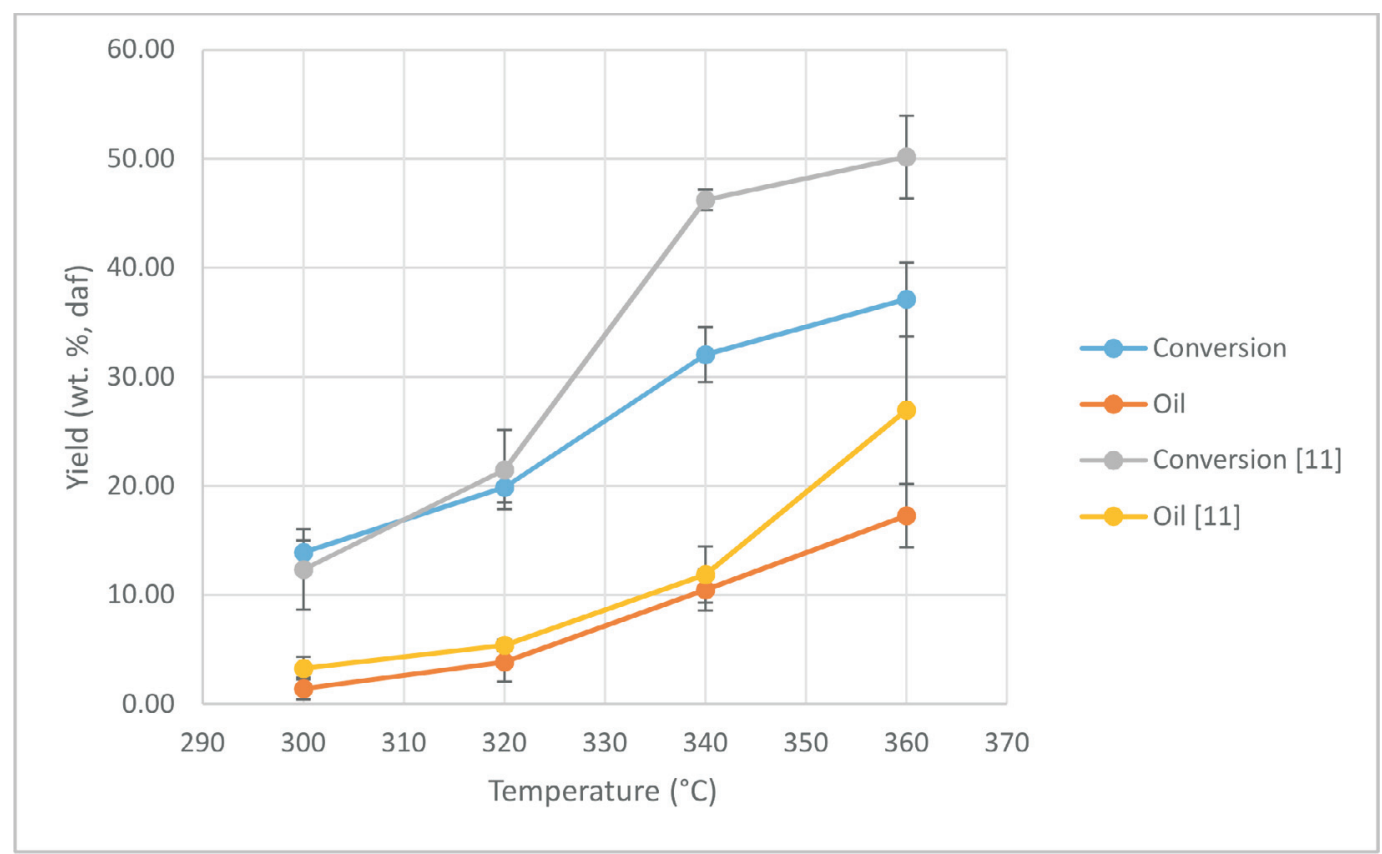

Figure 5 Coal conversion and oil yields using a model biomass-derived phenolic mixture and phenol. ${ }^{11}$

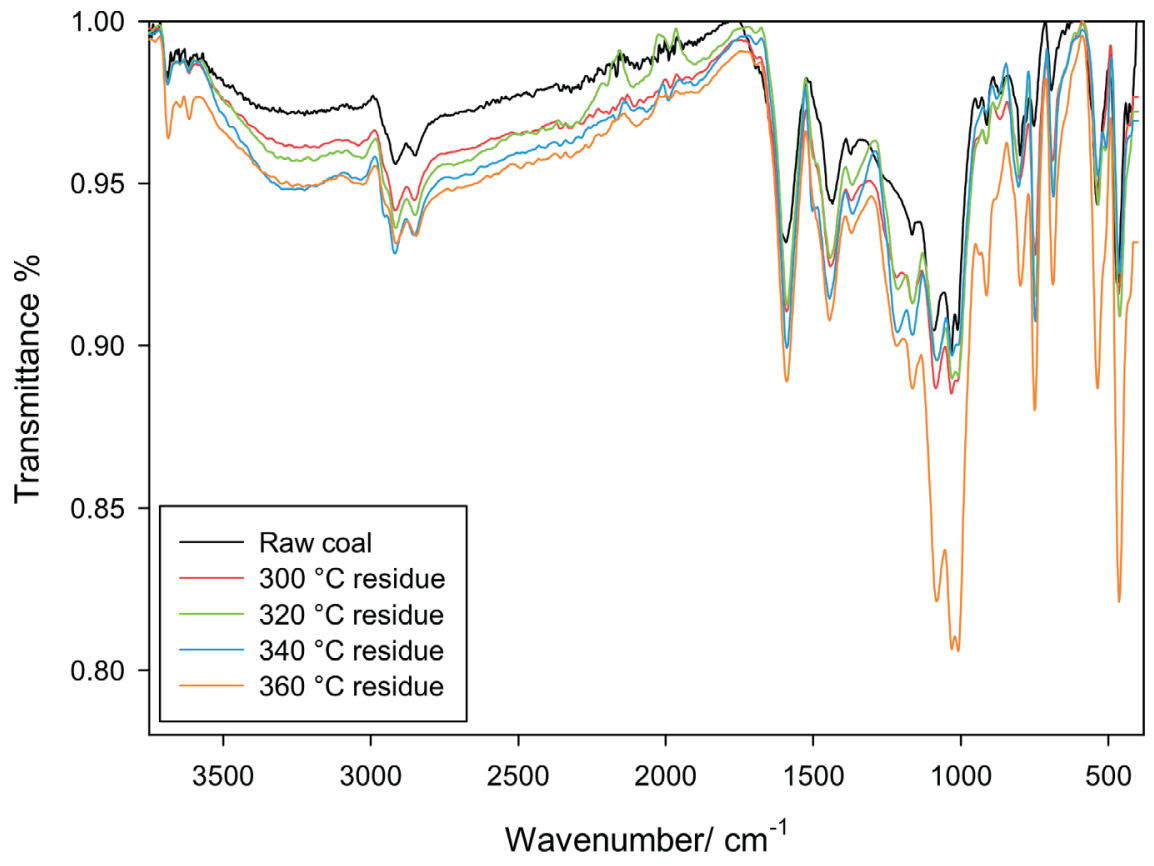

Figure 6 The infrared spectrum of the coal sample and unreacted coal residues (THFIs) after the coal solvent extraction at temperatures between $300{ }^{\circ} \mathrm{C}$ and $360{ }^{\circ} \mathrm{C}$, using a model biomass-derived phenolic mixture.

Table 3 Characteristic ATR-FTIR bands of functional groups.

\begin{tabular}{lll}
\hline $\begin{array}{c}\text { Wavenumber } \\
\left(\mathrm{cm}^{-1}\right)\end{array}$ & Assignment & Reference(s) \\
\hline $3600-3100$ & O-H stretching vibrations of hydrogen-bonded hydroxyl groups & $11,36,37$ \\
$3100-2800$ & Aromatic C-H stretching mode & $11,36,38$ \\
$3000-2800$ & Aliphatic C-H stretching mode & $11,36,39$ \\
$2900-2800$ & Aliphatic C-H stretching mode & $11,36,40$ \\
1600 & Aromatic ring (C=C in plane) stretching symmetric & 37,39 \\
1450 & Symmetric aliphatic C-H deformation of methylene & $11,36,40$ \\
$1133-1060$ & Stretching vibration of the ether groups, C-O stretch and OH bending vibrations & 39 \\
$900-650$ & Assigned to the C-H out-of-plane vibration of aromatic ring structures & 40,41
\end{tabular}




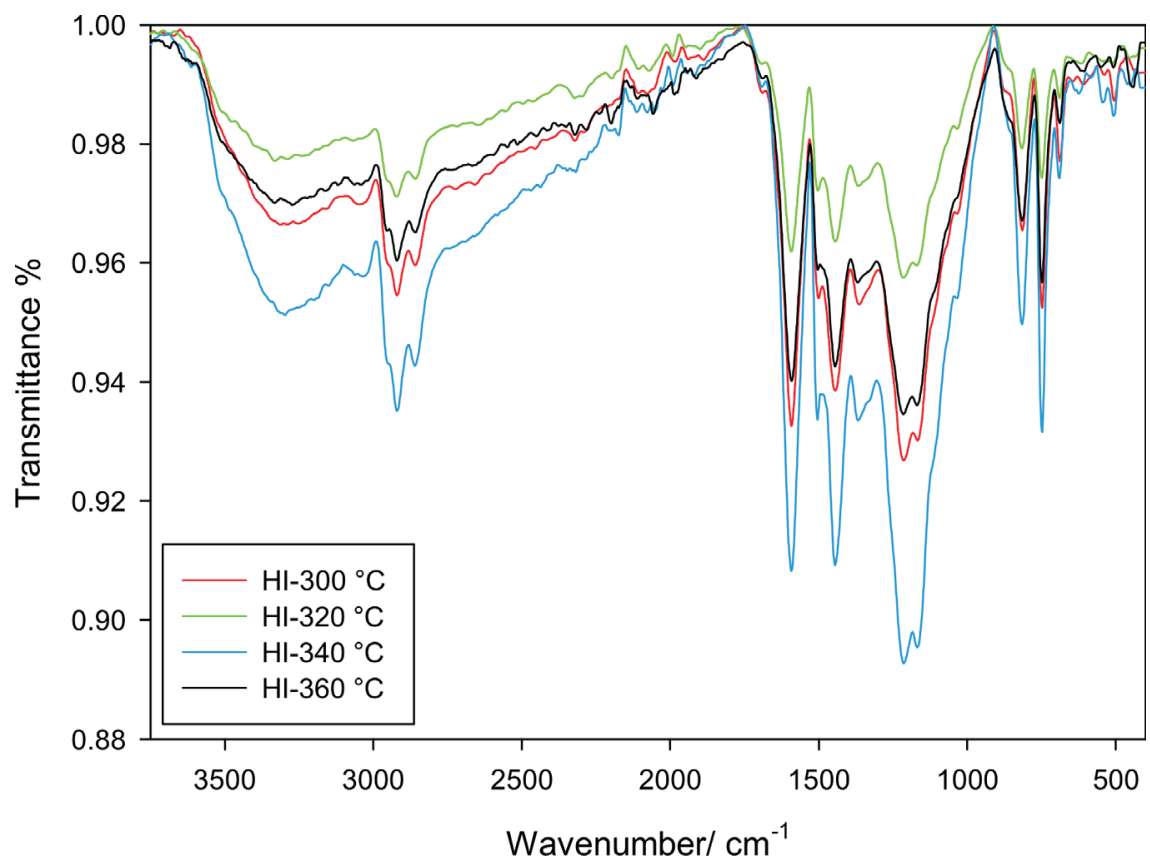

Figure 7 The infrared spectrum of hexane-insoluble products (PAAs) after the coal solvent extraction at temperatures between $300{ }^{\circ} \mathrm{C}$ and $360{ }^{\circ} \mathrm{C}$, using a model biomass-derived phenolic mixture.

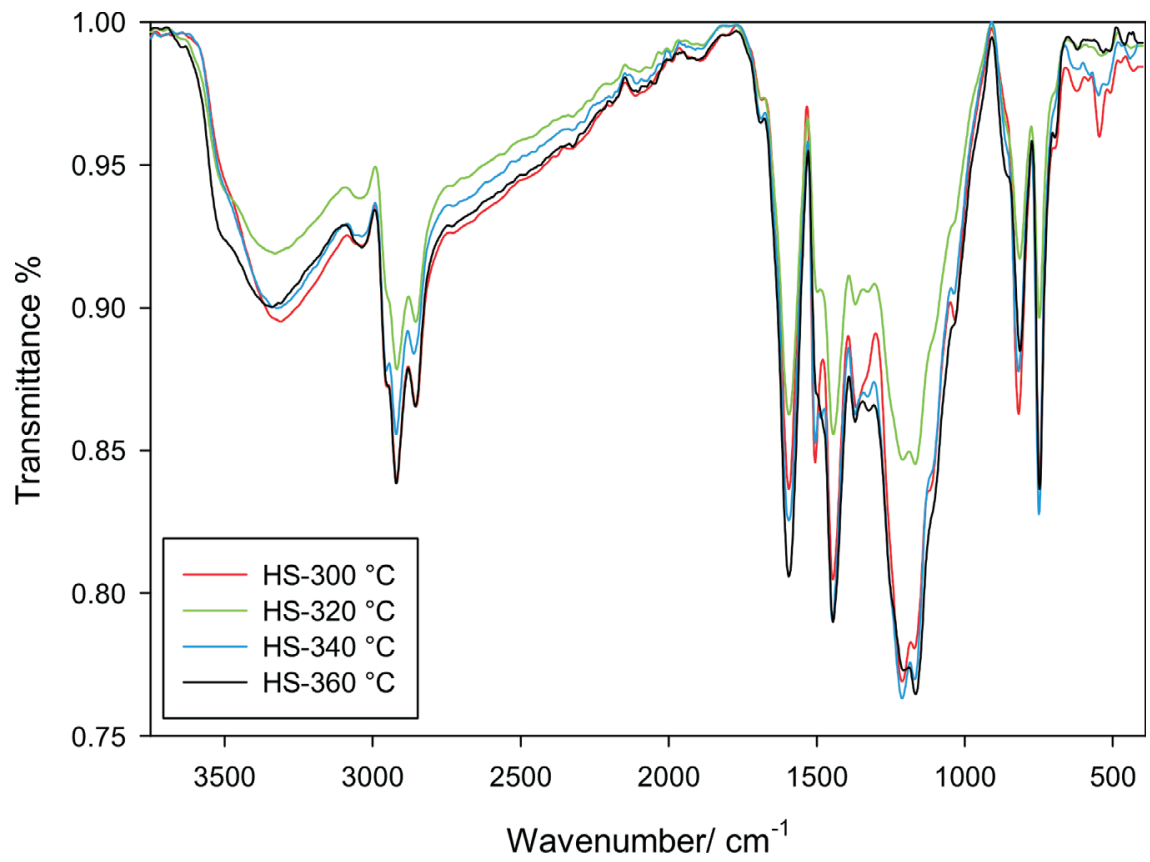

Figure 8 The infrared spectrum of the hexane soluble products (oil) after the coal solvent extraction at temperatures between $300^{\circ} \mathrm{C}$ and $360^{\circ} \mathrm{C}$, using a model biomass-derived phenolic mixture.

therefore, indicate a similar extraction process for pure phenol and a model biomass-derived phenolic mixture despite the differences in the extraction yields (see Section 3.3).

\subsection{SimDis GC Analysis}

The distillation curves of the coal-derived liquefied HS fractions obtained through coal extraction using a model biomass-derived phenolic mixture at the temperature range of $300-360^{\circ} \mathrm{C}$, are shown in Fig. 9. The fractionation of coal liquids is based largely on schemes modified and developed for the characterization of petroleum. ${ }^{44-47}$ It is important to note that the evaluation of the distillation curves of the HS fractions has been determined on a phenol-free basis due to the hindrance of the phenols peak that masks the low boiling point fraction
(79-191 ${ }^{\circ} \mathrm{C}$ ) peaks..$^{11}$ The HS fractions contain compounds with a wide range of boiling points $\left(208-520^{\circ} \mathrm{C}\right)$ with about $40 \%$ of the composition distilling off below $\approx 360{ }^{\circ} \mathrm{C}$. The HS fractions produced at $360^{\circ} \mathrm{C}$ yielded the highest boiling point distribution with regard to constant recovered mass, followed by fractions produced at $340{ }^{\circ} \mathrm{C}, 320^{\circ} \mathrm{C}$, and $300{ }^{\circ} \mathrm{C}$. For components boiling below $500{ }^{\circ} \mathrm{C}$, the variation of boiling point distributions when phenol was used as a solvent was the reverse; the highest boiling point distribution was observed for the extract produced at $300{ }^{\circ} \mathrm{C}$, and the lowest for the $360^{\circ} \mathrm{C}$ extract. The present study shows that the properties of the HS fractions were affected by the type of solvent; considering that the coal and process conditions were kept the same throughout the extractions using pure phenol and using the model phenolic mixture $\left(300-360^{\circ} \mathrm{C}\right)$. 


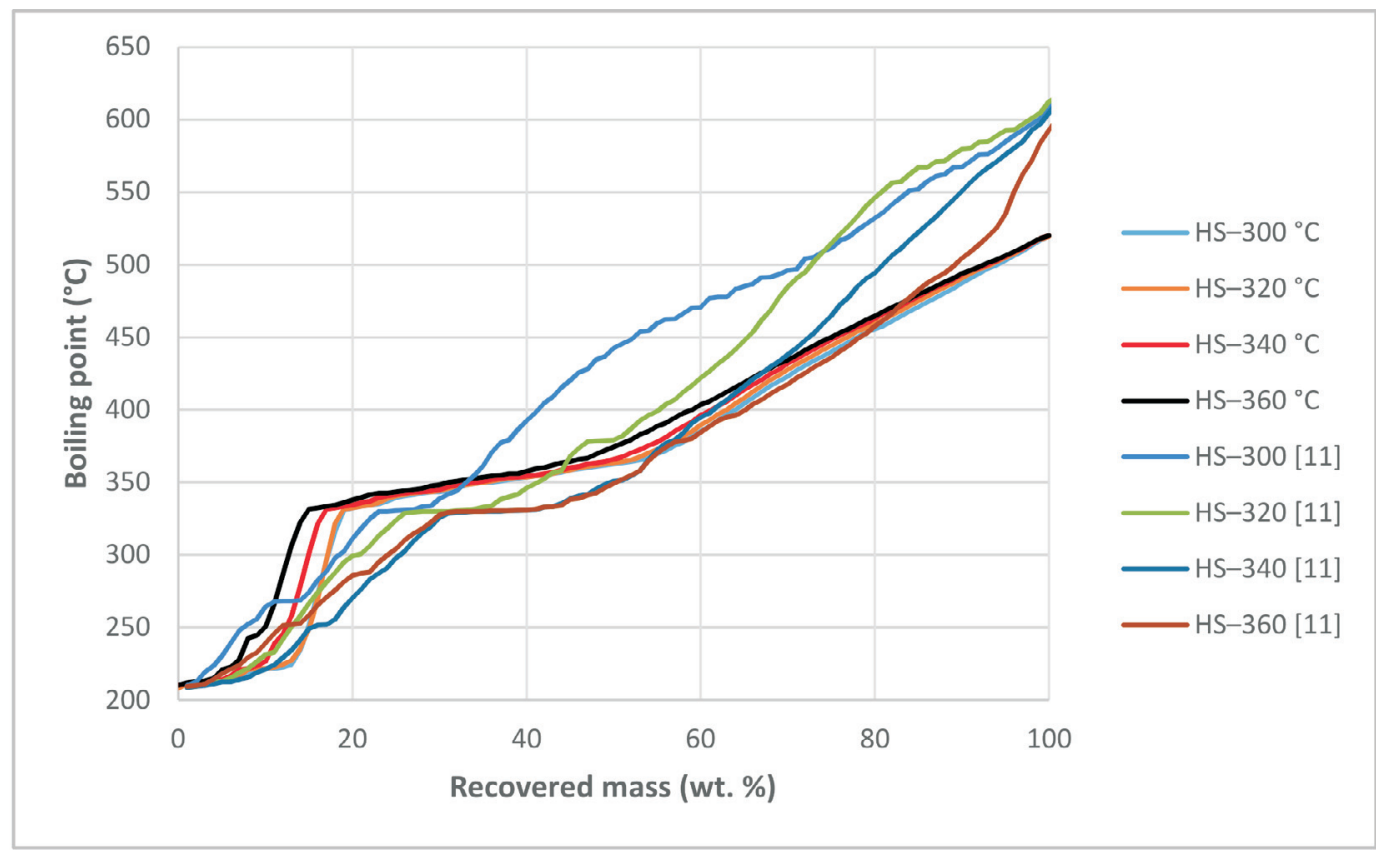

Figure 9 Distillation curves of the HS products obtained using a model biomass-derived phenolic mixture and phenol ${ }^{11}$ at different extraction temperatures.

Table 4 Boiling point distributions for the different HS fractions based on crude oil fractions obtained using a model biomass-derived phenolic mixture and pheno $^{11}$ as extraction solvent.

\begin{tabular}{|c|c|c|c|c|c|c|c|c|c|c|}
\hline $\begin{array}{l}\text { Boiling fraction/ } \\
\text { definition }\end{array}$ & $\begin{array}{l}\text { Boiling } \\
\text { range } /{ }^{\circ} \mathrm{C}\end{array}$ & Unit & $\begin{array}{l}\text { HS- } \\
300^{\circ} \mathrm{C}\end{array}$ & $\begin{array}{c}\text { HS- } \\
300^{\circ} \mathrm{C}^{11}\end{array}$ & $\begin{array}{l}\text { HS- } \\
320^{\circ} \mathrm{C}\end{array}$ & $\begin{array}{c}\text { HS- } \\
320^{\circ} \mathrm{C}^{11}\end{array}$ & $\begin{array}{l}\text { HS- } \\
340^{\circ} \mathrm{C}\end{array}$ & $\begin{array}{c}\text { HS- } \\
340{ }^{\circ} \mathrm{C}^{11}\end{array}$ & $\begin{array}{l}\text { HS- } \\
360^{\circ} \mathrm{C}\end{array}$ & $\begin{array}{c}\text { HS- } \\
360^{\circ} \mathrm{C}^{11}\end{array}$ \\
\hline Medium naphtha & $79-121$ & wt. $\%$ & - & - & - & - & - & - & - & - \\
\hline Heavy naphtha & $121-191$ & wt. $\%$ & _- & _ & _- & _ & - & _- & _- & - \\
\hline Kerosene & $191-277$ & wt. $\%$ & 16.0 & 14.0 & 16.0 & 15.0 & 14.0 & 20.0 & 11.0 & 17.0 \\
\hline Distillate fuel oil & $277-343$ & wt. $\%$ & 14.0 & 16.0 & 13.0 & 23.0 & 14.0 & 26.0 & 14.0 & 30.0 \\
\hline Light vacuum gas oil & $343-455$ & wt. $\%$ & 50.0 & 23.0 & 49.0 & 27.0 & 49.0 & 26.0 & 52.0 & 31.0 \\
\hline Heavy vacuum gas oil & $455-566$ & wt. $\%$ & 20.0 & 34.0 & 22.0 & 18.0 & 23.0 & 19.0 & 23.0 & 18.0 \\
\hline Residual oil & $>566$ & wt. $\%$ & - & 12.0 & - & 16.0 & - & 8.0 & - & 3.0 \\
\hline Total & - & wt. $\%$ & 100.0 & 99.0 & 100.0 & 99.0 & 100.0 & 99.0 & 100.0 & 99.0 \\
\hline Initial boiling point & - & ${ }^{\circ} \mathrm{C}$ & 208.8 & 209.8 & 208.0 & 208.6 & 210.2 & 208.6 & 210.2 & 209.2 \\
\hline $\begin{array}{l}\text { Average boiling point } \\
\text { (WABP) }\end{array}$ & $100-550$ & ${ }^{\circ} \mathrm{C}$ & 367.56 & 424.6 & 370.2 & 403.0 & 372.4 & 380.7 & 380.2 & 371.6 \\
\hline Final boiling point & _- & ${ }^{\circ} \mathrm{C}$ & 519.4 & 615.4 & 519.4 & 615.6 & 520.0 & 612.4 & 520.0 & 600.6 \\
\hline
\end{tabular}

The boiling point distribution of HS fractions using a model biomass-derived phenolic mixture for coal extraction are summarized in Table 4. The quality of the oil obtained depends significantly on its boiling point distribution. ${ }^{42}$ The boiling point fraction of kerosene decreases as the extraction temperature increases (16-11 wt. \%). The study shows that the extraction temperature has little effect on the number of products in the boiling fractions, with the distillate fuel oil, light vacuum gas oil and heavy vacuum gas oil fractions remaining the same with values of approximately $14 \mathrm{wt}$. $\%, 50 \mathrm{wt} . \%$, and $22 \mathrm{wt}$. \%, respectively. The largest proportion of the boiling fractions obtained with the model biomass-derived phenolic mixture could be arranged in decreasing order of light vacuum gas oil, heavy vacuum gas oil, distillate fuel oil, and kerosene $\left(300-360{ }^{\circ} \mathrm{C}\right)$. From these results, nearly $70 \%$ of the total fractions corresponded to light vacuum gas oil (LVGO) and heavy vacuum gas oil (HVGO), with about $50 \%$ correlating with LVGO which were obtained at low extraction temperatures. The LVGO fractions through advanced processes (i.e. hydrocracking) can be used as a feedstock preferably to produce $\mathrm{C}_{3}-\mathrm{C}_{4}$ compounds, light, and middle distillates.

The average boiling point of the hydrocarbon constituents of the fractions was calculated as shown in a previous study. ${ }^{11}$ It can be observed that the average boiling point (WABP) of HS fractions obtained using a model biomass-derived phenolic mixture increased with extraction temperatures from 368 to $380^{\circ} \mathrm{C}$ (Table 4). This trend is in contrast with the results obtained by using phenol as the extraction solvent where the WABP of HS fractions decreased with extraction temperatures $\left(425-372{ }^{\circ} \mathrm{C}\right) .{ }^{11}$ Thus, the decrease in average boiling points may be related to the difference in the average molecular mass of the extracts obtained using these solvents.

\section{Conclusions}

The utilization of a model biomass-derived phenolic mixture for the solvent extraction of a South African bituminous coal under mild conditions was investigated. The choice of a phenolic mixture as a model for the extraction of bituminous coal allowed this study to investigate the feasibility of coal extraction using a biomass-derived solvent. This model biomass-derived phenolic mixture was found to be effective in extracting 14-37 wt. \% of coal with increasing temperature $\left(300{ }^{\circ} \mathrm{C}\right.$ up to $360{ }^{\circ} \mathrm{C}$ ). Alkyl-substituted phenols showed less depolymeriza- 
tion ability than compared with phenol may be due to poor hydrogen carrier capability. The extraction yields were influenced by the effect of physical properties of the solvent used in coal extraction.

The THFIs and PAAs obtained using a model biomass-derived mixture had similar $\mathrm{H} / \mathrm{C}$ atomic ratios, which are similar to the $\mathrm{H} / \mathrm{C}$ of the coal. These results confirm that PAAs are the intermediate product coal and oil in coal extraction. The drop of the PAAs yield between $340{ }^{\circ} \mathrm{C}$ and $360{ }^{\circ} \mathrm{C}$ during coal conversion corresponded with an increase of the oil yields as a function of temperature. The ATR-FTIR spectra of the coal and the extraction products showed nearly the same functional groups with no significant structural changes. These results show that the extraction production of the phenol-based solvents during coal extraction are of a similar chemical nature, despite differences in the extraction yields.

SimDis results showed that the increasing extraction temperature influenced the number of products in the boiling fractions. The differences in the boiling point distribution obtained using phenolic based solvents may be related to the difference in average molecular mass of the extracts during coal extraction $\left(300-360^{\circ} \mathrm{C}\right)$. However, more work ought to be carried out using biomass-derived phenolic solvent to examine the nature of the extracts (i.e. carbon distribution and the molecular weight distribution) and all alkyl-substituted phenols that may lead to higher extractions at maximum experimental conditions. The utilization of a biomass-derived solvent will assist in the facilitation of the production of useful liquids from South African coals and address environmental challenges associated with the currently favoured approach of producing synthetic liquid fuels, indirect coal liquefaction.

\section{Acknowledgements}

The authors thank Mr Kgutso Mokoena (Sasol) for SimDis analysis. The work presented in this paper is based on research financially supported by the South African Research Chairs Initiative of the Department of Science and Technology and National Research Foundation of South Africa (Coal Research Chair Grant No. 86880, UID85643, Grant No. TP1208137225). Any opinion, finding, conclusion, or recommendation expressed in this material is that of the authors(s), and the NRF does not accept any liability in this regard.

\section{Conflict of interest}

The authors declare no conflict of interest.

\section{${ }^{8}$ ORCID iDs}

T.Z. Sehume:

C.A. Strydom:

J.R. Bunt:

H.H. Schobert:

orcid.org/0000-0002-3814-8727

orcid.org/0000-0001-5295-2095

orcid.org/0000-0003-3051-2528

orcid.org/0000-0001-6758-7174

\section{References}

1 H. Winkler, O. Davidson, A. Kenny, G. Prasad, J. Nkomo, D. Sparks, M. Howells and T. Alfstad, Energy policies for sustainable development in South Africa, Energy Research Centre, University of Cape Town, April 2006, pp. 1-4 \& 13-60.

2 R. Falcon and M. van der Riet, in Effect of milling and coal quality on combustion, International Pittsburgh Coal Conference, Sandton, South Africa, 2007.

3 Department of Minerals and Energy (DME), 2006, Energy Security Master Plan - Liquid Fuels.

4 J. Fletcher, Q. Sun, R. Bajura, Y. Zhang and X. Ren, Coal to clean fuelThe Shenhua investment in direct coal liquefaction, in 21st Annual International Pittsburgh Coal Conference, Osaka, Japan, 13-17 September, 2004.
5 P. Nolan, A. Shioman and H. Rui, Coal liquefaction, Shenhua Group, and China's energy security, Eur. Manage. J., 2004, 22, 150-164.

6 L. Zhao and K. Gallagher, Research, development, demonstration, and early deployment policies for advanced-coal technology in China, Energy Policy, 2007, 35, 6467-6477.

7 P. Barta, South Africa has a way to get more oil; make it from coal, WSJ, 2006, CCXLVIII, 1.

8 A. Andrews and J. Logan, Fischer-Tropsch fuels from coal, natural gas and biomass: background and policy, Congressional Research Service (CRS) Report for Congress, Order Code RL34133, 27 March 2008, pp. $1-26$.

9 T.M. Aida, T. Sato, G. Sekiguchi, T. Adschiri and K. Arai, Extraction of Taiheiyo coal with supercritical water-phenol mixtures, Fuel, 2002, 81, 1453-1461.

10 J.G. Speight and S.E. Moschopedis, The co-processing of coal with heavy feedstock, Fuel Process. Technol., 1986, 13, 215-232.

11 T.Z. Sehume, C.A. Strydom, J.R. Bunt and H.H. Schobert, Effectivity of phenol during solvent extraction of a South African bituminous coal at mild conditions, Energy \& Fuels, 2017, 31, 13655-13665.

12 T. Kabe, A. Ishihara, E.W. Qian, E.I.P. Sutrisna and Y. Kabe, Coal and Coal-related Compounds: Structures, Reactivity and Catalytic Reactions, Studies in Surface Science and Catalysis series, 150, Elsevier, Amsterdam, 2004.

13 M.W. Kiebler, The action of solvents on coal, in Chemistry of Coal Utilization (H.H. Lowry, ed.), Wiley, New York, 1945, pp. 677-760.

14 S.R. Illingworth, The action of solvents on coal, Fuel Sci. Pract., 1922,1, 213-219.

15 S.W. Parr and H.F. Hadley, The analysis of coal with phenol as a solvent, Fuel, 1925, 4, 31, 49.

16 A. Pott, H. Broche and W. Scheer, Solution of coal by pressure extraction and hydrogenation of the extracts, Glückauf, 1933, 69, 903-912.

17 J.G. Speight, The Chemistry and Technology of Coal, 3rd edn., CRC-Taylor and Francis Group, Boca Raton, FL, 2013, chapters 11 and 13.

18 M.I. Kuznetzov, The action of organic solvents on coal, Fuel, 1937, 16, 114-121.

19 N. Berkowitz, An Introduction to Coal Technology, Energy Science and Engineering, Academic Press Series, 1979, chapter 7.

20 M. Orchin and H.H Storch, Solvation and hydrogenation of coal, Ind. Eng. Chem., 1948, 40, 1385-1389.

21 A.C. Fieldner and P.M. Ambrose, Annual report of research and technologic work on coal, U.S. Bureau Mines, Information Circ. 7446, $1948,113 \mathrm{pp}$

22 S. Pande and D.K. Sharma, Ethylenediamine-assisted solvent extraction of coal in N-methyl-2 pyrrolidone: synergistic effect of ethylenediamine on extraction of coal in N methyl-2 pyrrolidone, Energy $\mathcal{E}$ Fuel, 2002, 16, 194-204.

23 M. Iino, T. Takanohashi, S. Obara, H. Tsueta and Y. Sanokawa, Characterization of the extracts and residues from CS2-N-methyl-2-pyrrolidinone mixed solvent extraction, Fuel, 1989, 68, 1588-1593.

24 K. Miura and T. Mae, Proceedings of the Society of Chemical Engineers Japan, 63rd Annual Meeting, 2000, p. G104.

25 M. Iino and M. Matsuda, Synergistic effects of alcohol-benzene mixture for coal extraction, Bull. Chem. Soc. Jpn., 1984, 57, 3290-3294.

26 K. Miura, K. Mae, T. Yoshimura, K. Masuda and K. Hashimoto, A new coal flash pyrolysis method utilizing effective radical transfer from solvent to coal, Energy \& Fuels, 1991, 5, 803-808.

27 T.Z. Sehume, C.A. Strydom, J.R. Bunt and H.H. Schobert, Bio-oil production from sweet sorghum bagasse via liquefaction using alkaline solutions and identification of phenolic products, Waste $\mathcal{E}$ Biomass Valorization, submitted for publication, 2019 (Manuscript number WAVE-D-19-00223).

28 L.J. Darlage and M. Bailey, Solvent effects in the depolymerization of coal, Fuel, 1976, 55, 205-210.

29 J.C. Pew and J.R. Withrow, Action of various solvents on coal, Fuel, 1931, 10, 44-47.

30 M.W. Kiebler, Extraction of a bituminous coal-influence of the nature of solvents, Ind. Eng. Chem., 1940, 32, 1389-1394.

31 J.W. Larsen, T.L. Sams and B.R. Rodgers, Internal rearrangement of hydrogen during heating of coals with phenol, Fuel, 1981, 60, 335-341.

32 For a thorough discussion of the chemistry of phenoxy radicals see: Scott, G. Atmospheric Oxidation and Antioxidents, Elsevier Publishing Co., New York, 1965. 
33 H.H. Schobert, Chemistry of Fossil Fuels and Biofuels, Cambridge University Press, Cambridge, New York, 2013, chapter 22.

34 D.H. Buchanan, Status of coal research: solvent extraction, Fuel Chemical Division, American Chemical Society (ACS) 1994, 39, 64-68.

35 J. Yan, J. Bai, W. Li and J. Bai, Direct liquefaction of a Chinese brown coal and $\mathrm{CO}_{2}$ gasification of the residues, Fuel, 2014, 136, 280-286.

$36 \mathrm{~K}$. Ouchi, K. Imuta and Y. Yamashita, Catalytic depolymerization of coal: depolymerization of Yubari coal by p-toluenesulphonic acid as catalyst, Fuel, 1965, 44, 29-38.

37 P.C. Painter, R.W. Snyder, M. Starsinic, M.M. Coleman, D.W. Kuehn and A. Davis, Concerning the application of FT-IR to the study of coal: a critical assessment of band assignments and the application of spectral analysis programs, Appl. Spectrosc., 1981, 35, 475-485.

38 P.C. Painter, M. Starsinic, E. Squires and A.A. Davis, Concerning the $1600 \mathrm{~cm}^{-1}$ region in the IR spectrum of coal, Fuel, 1983, 62, 742743.

39 D. Van Niekerk, R.J. Pugmire, M.S. Solum, P.C. Painter and J.P. Mathews, Structural characterization of vitrinite-rich and inertiniterich Permian-aged South African bituminous coals, Int. J. Coal Geol., 2008, 76, 290-300.

40 T.F. Yen, W.H. Wu and G.V. Chilingar, A study of the structure of petro- leum asphaltenes and related substances by infrared spectroscopy, Energy Sources, 1984, 7, 203-235.

41 J.V. Ibarra, E. Munoz and R. Moliner, FTIR study of the evolution of coal structure during the coalification process, Org. Geochem., 1996, 24, 725-735.

42 A. Sofianos and A. Butler, Catalytic liquefaction of South African coals using the carbon monoxide/water system. Part 2: Nature of the oils, Fuel Process. Technol., 1989, 22, 189-204.

43 D. Nag, P. Biswas, V.K. Chandaliya and P.K. Banerjee, Characterization of solvent extract of an Indian coal. Int. J. Coal Prep. Util., 2011, 31, $1-8$.

44 R.G. Ruberto, D.M. Jewell, R.K. Jensen and D.C. Cronauer, in Shale Oil, Tar Sands, and Related Fuel Sources, (T.F. Yen, ed.), Advances in Chemistry Series No. 151, American Chemical Society, Washington, DC, 1976, chapter 3.

45 J.E. Dooley, C.J. Thompson and S.E. Scheppele, in Analytical Methods for Coal and Coal Products, (C. Karr, Jr., ed.), Academic Press, New York, vol. I, 1978, chapter 16.

46 K.D. Bartle, in Spectroscopic Analysis of Coal Liquids, (J. Kershaw, ed.), Elsevier, Amsterdam, Netherlands, 1989, chapter 2.

47 J.G. Speight, Synthetic Fuels Handbook: Properties, Processes, and Performance, McGraw-Hill, New York, 2008. 